\title{
The LEAP program: lenvatinib plus pembrolizumab for the treatment of advanced solid tumors
}

\author{
Matthew H Taylor*,1, Emmett V Schmidt ${ }^{2}$, Corina Dutcus ${ }^{3}$, Elaine M Pinheiro², \\ Yasuhiro Funahashi ${ }^{4}$, Gregory Lubiniecki ${ }^{2}$ \& Drew Rasco ${ }^{5}$ \\ ${ }^{1}$ Earle A Chiles Research Institute, Providence Portland Medical Center, Portland, OR 97213, USA \\ ${ }^{2}$ Department of Clinical Oncology, Merck \& Co. Inc., Kenilworth, NJ 07033, USA \\ ${ }^{3}$ Department of Clinical Research, Eisai Inc., Woodcliff Lake, NJ 07677, USA \\ ${ }^{4}$ Biomarker Research Translational Science Department, Eisai Co., Ltd., Tokyo, 112-0002, Japan \\ ${ }^{5}$ The START Center for Cancer Care, San Antonio, TX 78229, USA \\ *Author for correspondence: Tel.: +1 503215 5696; matthew.taylor@providence.org
}

Tumor progression and immune evasion result from multiple oncogenic and immunosuppressive signals within the tumor microenvironment. The combined blockade of VEGF and inhibitory immune checkpoint signaling has been shown to enhance immune activation and tumor destruction in preclinical models. The LEAP clinical trial program is evaluating the safety and efficacy of lenvatinib (a multikinase inhibitor) plus pembrolizumab (a PD-1 inhibitor) across several solid tumor types. Preliminary results from ongoing trials demonstrate robust antitumor activity and durable responses across diverse tumor types with a manageable safety profile. Thus, lenvatinib plus pembrolizumab is anticipated to be an important potential new regimen for several solid cancers that currently have limited therapeutic options.

Clinical trial registration: NCT03884101, NCT03713593, NCT03820986, NCT03776136, NCT03797326, NCT03829319, NCT03829332, NCT03976375, NCT04428151, NCT04199104, NCT03898180, NCT04246177 (ClinicalTrials.gov).

Lay abstract: Over the last 20 years, several new drugs have been developed that have greatly improved outcomes for patients with cancer. However, some patients have tumors that do not respond or become unresponsive to treatment over time when a given drug is used as the sole treatment. To overcome this problem, combinations of drugs that attack the tumor in different ways are being studied. Here, we describe the rationale and design of the LEAP clinical trial program, which is investigating the combination of pembrolizumab and lenvatinib in patients with several solid tumor types who currently have limited available therapies. Pembrolizumab works with the patient's immune system to attack cancer cells whereas lenvatinib targets angiogenesis, a process that promotes tumor growth by suppling nutrients and oxygen. In early phase trials, the combination of pembrolizumab and lenvatinib has been shown to provide robust antitumor activity, durable responses and manageable safety.

First draft submitted: 11 September 2020; Accepted for publication: 7 October 2020; Published online: 10 December 2020

Keywords: combination therapy • LEAP program • lenvatinib • pembrolizumab • solid tumors

Advances in understanding immune regulation and cancer immunobiology have led to the development of novel agents targeting various immune checkpoint molecules including CTLA- 4 and the PD-1/PD-L1 axis [1]. In addition, a number of tyrosine kinase inhibitors (TKIs) have been developed over the last two decades that target multiple signaling pathways [2]. Collectively, these developments have transformed the standard of care for several advanced cancers [3]. However, innate and acquired resistance to monotherapy with immune checkpoint inhibitors and TKIs remains a challenge $[2,4,5]$. Consequently, there is much interest in the use of combination therapies to simultaneously target multiple signaling pathways to overcome the mechanisms of resistance. The LEAP clinical trial program is designed to evaluate the safety and efficacy of the combination of lenvatinib, a multi-TKI and pembrolizumab, a PD-1 inhibitor, for a broad range of solid cancers. This combination therapy targets multiple

Future : Medicine 
tumor intrinsic molecular abnormalities (excessive VEGF and FGF signaling) as well as immune inhibitory signaling through PD-1 [6,7]. Early results from a study investigating lenvatinib and pembrolizumab in combination have shown improved efficacy and response durability in several advanced solid tumors [8]. The combination of lenvatinib and pembrolizumab may provide clinical benefit to a broad patient population across multiple tumor types.

\section{Lenvatinib}

Lenvatinib is an oral small-molecule inhibitor of VEGFRs, FGFRs, PDGFR $\alpha$, KIT and RET proto-oncogene [7,9]. Several of these receptor tyrosine kinases (RTKs) are overexpressed in multiple cancers [10]. In a preclinical investigation, lenvatinib inhibited VEGF- and FGF-driven angiogenesis and demonstrated antitumor activity in human xenograft tumor models [11].

In addition to antiangiogenic and antiproliferative activity, lenvatinib has shown immunomodulatory properties in preclinical models. In a syngeneic mouse tumor model, lenvatinib increased tumor infiltration of $\mathrm{CD} 8^{+} \mathrm{T}$ cells expressing granzyme B and IFN- $\gamma$, plasmacytoid dendritic cells and decreased tumor-associated macrophages (TAMs) [12]. TAMs, derived from blood monocytes, influence tumor cell survival, proliferation and dissemination and produce a range of molecules that attenuate the antitumor immune response [13,14].

VEGF signaling modulates the tumor microenvironment and also plays an important role in regulating T-cell activation. VEGF signaling in T-cells results in increased expression of multiple inhibitory immune checkpoint molecules including PD-1, CTLA-4, TIM-3 and LAG-3 [15]. High tumor expression of VEGF is also correlated with increased intratumoral Tregs [16]. Inhibition of VEGF signaling has been shown to decrease the number of intratumoral Tregs in patients with advanced renal cell carcinoma as well as preclinical mouse models [16]. FGFR1 signaling promotes the survival and migration of TAMs into tumors [17]. Therefore, inhibition of VEGFR and FGFR1 signaling by lenvatinib may lead to TAM depletion and promote antitumor immunological responses.

Lenvatinib is administered orally as monotherapy for the treatment of radioactive iodine-refractory differentiated thyroid cancer and for the first-line treatment of unresectable hepatocellular carcinoma (HCC) [7,18]. Lenvatinib plus everolimus is approved as a second-line therapy for advanced renal cell carcinoma following one prior antiangiogenic therapy. Table 1 summarizes the indications approved by the US FDA for lenvatinib in the USA [7].

\section{Pembrolizumab}

Immunotherapies exploit the ability of the immune system to identify and eradicate tumors. PD-1 is a negative regulator of T-cell immunity, found primarily on the surface of activated T-cells [19]. On binding to its ligands PD-L1 or PD-L2, PD-1 can inhibit effector T-cell responses contributing to evasion of the antitumor immune response [20,21].

Pembrolizumab is a potent, highly selective, fully humanized monoclonal immunoglobulin G4K, anti-PD-1 antibody $(\mathrm{mAb})$ that blocks the interaction between PD-1 and its ligands, PD-L1 and PD-L2 [6]. PD-1 inhibition by pembrolizumab counteracts the downregulation of the antitumor immune response mediated by the PD1 pathway [6]. Pembrolizumab is administered by intravenous infusion and is currently indicated for a broad spectrum of solid and hematologic cancers (Table 1) [6,22].

\section{Rationale for lenvatinib plus pembrolizumab}

Combination immunotherapies that modulate different aspects of tumor immunobiology may help to overcome primary and acquired resistance to immunotherapy and may offer improved efficacy across a broad range of cancers [23]. The combination of lenvatinib and pembrolizumab is based on a strong mechanistic rationale. In syngeneic CT26 CRC and Hepa1-6 HCC murine tumor models, the combination of lenvatinib and an anti-PD-1 antibody produced greater reduction in tumor volume and a higher response rate than either agent alone, including complete regression of tumors in some animals [12,24]. The combination showed immunomodulatory properties: increased tumor infiltration of effector $\mathrm{CD}^{+} \mathrm{T}$ cells and decreased monocytes and macrophages [24].

The maximum tolerated dose, recommended Phase II dose and preliminary antitumor activity of lenvatinib plus pembrolizumab are being studied in patients with selected solid tumors in a Phase Ib/II, open-label, single-arm trial (study 111/KEYNOTE-146; NCT02501096). In the Phase Ib dose-finding portion of the study, toxicities were manageable and a maximum tolerated dose for the combination was identified; this dose was considered as the recommended Phase II dose [8]. Analysis of the expansion phase of the study demonstrated robust antitumor activity and durable response across six tumor types - urothelial cancer, head and neck squamous cell carcinoma 
Table 1. Indications as of 18 November 2020 for lenvatinib and pembrolizumab and lenvatinib in combination with pembrolizumab as approved by the US FDA.

\begin{tabular}{|c|c|c|}
\hline Tumor type & Monotherapy/combination & Details of indication ${ }^{\dagger}$ \\
\hline \multicolumn{3}{|l|}{ Lenvatinib } \\
\hline DTC & Monotherapy & Locally recurrent or metastatic, progressive, radioactive iodine-refractory DTC \\
\hline $\mathrm{RCC}$ & Combination with everolimus & Advanced RCC following one prior anti-angiogenic therapy \\
\hline $\mathrm{HCC}$ & Monotherapy & First-line treatment of unresectable HCC \\
\hline \multicolumn{3}{|l|}{ Pembrolizumab } \\
\hline \multirow[t]{2}{*}{ Melanoma } & Monotherapy & Unresectable or metastatic melanoma \\
\hline & Monotherapy & Adjuvant treatment of melanoma with involvement of lymph node(s) following complete resection \\
\hline \multirow[t]{4}{*}{ NSCLC } & $\begin{array}{l}\text { Combination with pemetrexed and } \\
\text { platinum chemotherapy }\end{array}$ & First-line treatment of metastatic nonsquamous NSCLC with no EGFR or $A L K$ genomic tumor aberrations \\
\hline & $\begin{array}{l}\text { Combination with carboplatin and } \\
\text { either paclitaxel or nab-paclitaxel }\end{array}$ & First-line treatment of metastatic squamous NSCLC \\
\hline & Monotherapy & $\begin{array}{l}\text { First-line treatment of NSCLC expressing PD-L1 (TPS } \geq 1 \% \text { ) as determined by an FDA-approved test, with } \\
\text { no } E G F R \text { or } A L K \text { genomic tumor aberrations and is: stage III where patients are not candidates for } \\
\text { surgical resection or definitive chemoradiation, or metastatic }\end{array}$ \\
\hline & Monotherapy & $\begin{array}{l}\text { Metastatic NSCLC tumors expressing PD-L1 (TPS } \geq 1 \% \text { ) as determined by an FDA-approved test, with } \\
\text { disease progression on or after platinum-containing chemotherapy. Patients with } E G F R \text { or } A L K \text { genomic } \\
\text { tumor aberrations should have disease progression on FDA-approved therapy for these aberrations } \\
\text { prior to receiving pembrolizumab }\end{array}$ \\
\hline SCLC & Monotherapy & $\begin{array}{l}\text { Metastatic SCLC with disease progression on or after platinum-based chemotherapy and at least one } \\
\text { other prior line of therapy } \ddagger\end{array}$ \\
\hline \multirow[t]{3}{*}{ HNSCC } & Combination with platinum and FU & First-line treatment of metastatic or unresectable, recurrent HNSCC \\
\hline & Monotherapy & $\begin{array}{l}\text { First-line treatment of metastatic or unresectable, recurrent HNSCC tumors expressing PD-L1 (CPS } \geq 1) \text { as } \\
\text { determined by an FDA-approved test }\end{array}$ \\
\hline & Monotherapy & Recurrent or metastatic HNSCC with disease progression on or after platinum-containing chemotherapy \\
\hline \multirow[t]{2}{*}{$\mathrm{cHL}$} & Monotherapy & Adult patients with relapsed or refractory $\mathrm{cHL}$ \\
\hline & Monotherapy & Pediatric patients with refractory $\mathrm{cHL}$ or $\mathrm{cHL}$ that has relapsed after two or more lines of therapy \\
\hline PMBCL & Monotherapy & $\begin{array}{l}\text { Adult and pediatric patients with refractory } \mathrm{PMBCL} \text {, or who have relapsed after two or more prior lines } \\
\text { of therapy (not recommended for treatment of patients with } \mathrm{PMBCL} \text { who require urgent cytoreductive } \\
\text { therapy) }\end{array}$ \\
\hline \multirow[t]{3}{*}{ Urothelial carcinoma } & Monotherapy & $\begin{array}{l}\text { Locally advanced or metastatic urothelial carcinoma not eligible for cisplatin-containing chemotherapy } \\
\text { and with tumors expressing PD-L1 (CPS } \geq 10 \text { ) as determined by an FDA-approved test, or in patients who } \\
\text { are not eligible for any platinum-containing chemotherapy regardless of PD-L1 status } \$\end{array}$ \\
\hline & Monotherapy & $\begin{array}{l}\text { Locally advanced or metastatic urothelial carcinoma with disease progression during or following } \\
\text { platinum-containing chemotherapy or within } 12 \text { months of neoadjuvant or adjuvant treatment with } \\
\text { platinum-containing chemotherapy }\end{array}$ \\
\hline & Monotherapy & $\begin{array}{l}\text { BCG-unresponsive, high risk, nonmuscle invasive bladder cancer with carcinoma in situ with or without } \\
\text { papillary tumors who are ineligible for or have elected not to undergo cystectomy }\end{array}$ \\
\hline MSI-H cancers & Monotherapy & $\begin{array}{l}\text { Adult and pediatric patients with unresectable or metastatic, MSI-H or dMMR: } \\
\text { - Solid tumors that have progressed following prior treatment and who have no satisfactory alternative } \\
\text { treatment options } \ddagger \\
\text { - CRC that has progressed following treatment with a fluoropyrimidine, oxaliplatin and irinotecan } \ddagger \\
\text { The safety and effectiveness of pembrolizumab in pediatric patients with MSI-H CNS cancers is not yet } \\
\text { established }\end{array}$ \\
\hline MSI-H or dMMR CRC & Monotherapy & First-line treatment of unresectable or metastatic MSI-H or dMMR CRC \\
\hline Gastric cancer & Monotherapy & $\begin{array}{l}\text { Recurrent locally advanced or metastatic gastric or gastroesophageal junction adenocarcinoma with } \\
\text { tumors expressing PD-L1 (CPS } \geq 1 \text { ) as determined by an FDA-approved test, with disease progression on } \\
\text { or after two or more prior lines of therapy including fluoropyrimidine- and platinum-containing } \\
\text { chemotherapy and if appropriate, HER2/neu-targeted therapy } \ddagger\end{array}$ \\
\hline \multicolumn{3}{|c|}{$\begin{array}{l}\text { †Details taken from }[6,7] \text {. } \\
\text { ¥This indication is approved under accelerated approval based on tumor response rate and durability of response. Continued approval for this indication may be contingent upon } \\
\text { verification and description of clinical benefit in the confirmatory trials. } \\
\S \text { This indication is approved under accelerated approval based on progression-free survival. Continued approval for this indication may be contingent upon verification and description of } \\
\text { clinical benefit in the confirmatory trials. } \\
\text { IThis indication is approved under accelerated approval based on pharmacokinetic data, the relationship of exposure to efficacy, and the relationship of exposure to safety. Continued } \\
\text { approval for this dosing may be contingent upon verification and description of clinical benefit in the confirmatory trials. } \\
\text { BCG: Bacillus Calmette-Guérin; CHL: Classical Hodgkin lymphoma; CNS: Central nervous system; CPS: Combined positive score; CRC: Colorectal cancer; cSCC: Cutaneous squamous cell } \\
\text { carcinoma; dMMR: Mismatch repair-deficient; DTC: Differentiated thyroid cancer; FU: Fluorouracil; HCC: Hepatocellular carcinoma; HNSCC: Head and neck squamous cell carcinoma; } \\
\text { MSI-H: Microsatellite instability high; NSCLC: Non-small-cell lung cancer; PMBCL: Primary mediastinal large B-cell lymphoma; RCC: Renal cell carcinoma; SCLC: Small cell lung cancer; } \\
\text { TMB-H: Tumor mutational burden high; TNBC: Triple-negative breast cancer; TPS: Tumor proportion score. } \\
\text { Reproduced with permission from }[6,7] \text {. }\end{array}$} \\
\hline
\end{tabular}


Table 1. Indications as of 18 November 2020 for lenvatinib and pembrolizumab and lenvatinib in combination with pembrolizumab as approved by the US FDA (cont.).

\begin{tabular}{|c|c|c|}
\hline Tumor type & Monotherapy/combination & Details of indication ${ }^{\dagger}$ \\
\hline Esophageal cancer & Monotherapy & $\begin{array}{l}\text { Recurrent locally advanced or metastatic squamous cell carcinoma of the esophagus with tumors } \\
\text { expressing PD-L1 (CPS } \geq 10 \text { ) as determined by an FDA-approved test, with disease progression after one } \\
\text { or more prior lines of systemic therapy }\end{array}$ \\
\hline Cervical cancer & Monotherapy & $\begin{array}{l}\text { Recurrent or metastatic cervical cancer with disease progression on or after chemotherapy with tumors } \\
\text { expressing PD-L1 }(C P S \geq 1) \text { as determined by an FDA-approved test } t^{\ddagger}\end{array}$ \\
\hline $\mathrm{HCC}$ & Monotherapy & HCC previously treated with sorafenib $\ddagger$ \\
\hline Merkel cell carcinoma & Monotherapy & Adult and pediatric patients with recurrent locally advanced or metastatic Merkel cell carcinoma $\ddagger$ \\
\hline $\mathrm{RCC}$ & Combination with axitinib & First-line treatment of advanced RCC \\
\hline TMB-H cancer & Monotherapy & $\begin{array}{l}\text { Adult and pediatric patients with unresectable or metastatic TMB-H ( } \geq 10 \text { mutations/megabase) solid } \\
\text { tumors, as determined by an FDA-approved test, that have progressed following prior treatment and } \\
\text { who have no satisfactory alternative treatment options } \ddagger \\
\text { The safety and effectiveness of pembrolizumab in pediatric patients with TMB-H CNS cancers is not yet } \\
\text { established }\end{array}$ \\
\hline $\mathrm{CSCC}$ & Monotherapy & Recurrent or metastatic CSCC that is not curable by surgery or radiation ${ }^{\ddagger}$ \\
\hline TNBC & Combination with chemotherapy & $\begin{array}{l}\text { Locally recurrent unresectable or metastatic TNBC with tumors expressing PD-L1 (CPS } \geq 10 \text { ) as } \\
\text { determined by an FDA-approved test }{ }^{\S}\end{array}$ \\
\hline Adult indications & Monotherapy & Use at an additional dosing regimen of $400 \mathrm{mg}$ every 6 weeks for all approved adult indications $\mathbb{I}$ \\
\hline \multicolumn{3}{|c|}{ Lenvatinib and pembrolizumab } \\
\hline Endometrial cancer & Combination & $\begin{array}{l}\text { Advanced endometrial cancer that is not MSI-H or dMMR with disease progression following prior } \\
\text { systemic therapy and who are not candidates for curative surgery or radiation } \ddagger\end{array}$ \\
\hline \multicolumn{3}{|c|}{$\begin{array}{l}\text { †Details taken from }[6,7] \text {. } \\
\text { ¥This indication is approved under accelerated approval based on tumor response rate and durability of response. Continued approval for this indication may be contingent upon } \\
\text { verification and description of clinical benefit in the confirmatory trials. } \\
\text { §This indication is approved under accelerated approval based on progression-free survival. Continued approval for this indication may be contingent upon verification and description of } \\
\text { clinical benefit in the confirmatory trials. } \\
\text { IThis indication is approved under accelerated approval based on pharmacokinetic data, the relationship of exposure to efficacy, and the relationship of exposure to safety. Continued } \\
\text { approval for this dosing may be contingent upon verification and description of clinical benefit in the confirmatory trials. } \\
\text { BCG: Bacillus Calmette-Guérin; CHL: Classical Hodgkin lymphoma; CNS: Central nervous system; CPS: Combined positive score; CRC: Colorectal cancer; cSCC: Cutaneous squamous cell } \\
\text { carcinoma; dMMR: Mismatch repair-deficient; DTC: Differentiated thyroid cancer; FU: Fluorouracil; HCC: Hepatocellular carcinoma; HNSCC: Head and neck squamous cell carcinoma; } \\
\text { MSI-H: Microsatellite instability high; NSCLC: Non-small-cell lung cancer; PMBCL: Primary mediastinal large B-cell lymphoma; RCC: Renal cell carcinoma; SCLC: Small cell lung cancer; } \\
\text { TMB-H: Tumor mutational burden high; TNBC: Triple-negative breast cancer; TPS: Tumor proportion score. } \\
\text { Reproduced with permission from }[6,7] \text {. }\end{array}$} \\
\hline
\end{tabular}

(HNSCC), melanoma, non-small-cell lung cancer (NSCLC), renal cell carcinoma and endometrial cancer (Table 2). Objective response rates ranged from 25 to $55 \%$ and median progression-free survival ranged from 4.7 to 11.7 months depending on the tumor type (Figure $1 \mathrm{~A} \& \mathrm{~B}$ ) $[8,25,26]$. Final results from the cohort of patients with metastatic endometrial cancer showed that the combination of lenvatinib plus pembrolizumab showed encouraging antitumor activity, irrespective of tumor microsatellite instability (MSI) high or mismatch repair deficient (dMMR) status, providing further support for efficacy of this combination [26]. Results from another Phase Ib study (study 116/KEYNOTE-524) demonstrated encouraging antitumor activity with lenvatinib plus pembrolizumab in 100 patients with previously untreated and unresectable HCC, with $11 \%$ of patients showing a complete response by independent imaging review per modified RECIST (Table 2) [27].

Based on the results of the study 111/KEYNOTE-146 trial, the combination of lenvatinib plus pembrolizumab was approved by the FDA, the Australian Therapeutic Goods Administration and Health Canada for the treatment of patients with advanced endometrial carcinoma that is not MSI high or dMMR, who have disease progression following prior systemic therapy and are not candidates for curative surgery or radiotherapy [28].

\section{Safety considerations}

In some cases, treatment combinations can result in additive or synergistic toxicities and severe adverse events arising from overlapping or unexpected toxicities [23]. However, the tolerability of lenvatinib-pembrolizumab combination therapy appears to be consistent with the safety of each individual agent.

Lenvatinib

Adverse events with lenvatinib monotherapy are comparable to those reported for other VEGFR targeting TKIs [29]. In a meta-analysis of lenvatinib clinical trials, encompassing 978 patients, the most frequent grade $\geq 3$ treatmentrelated adverse events (AEs) were thrombocytopenia (25.4\%), hypertension (17.7\%), peripheral edema (15.5\%) 


\begin{tabular}{|c|c|c|c|c|c|c|c|c|c|}
\hline Tumor type & $\mathbf{n}$ & $\begin{array}{l}\text { Line of } \\
\text { therapy }\end{array}$ & Data cut-off & ORR \% $(95 \% \mathrm{Cl})$ & $\begin{array}{l}\text { Median DOR, } \\
\text { months }(95 \% \mathrm{Cl})\end{array}$ & $\begin{array}{l}\text { Median PFS, } \\
\text { months }(95 \% \mathrm{Cl})\end{array}$ & $\begin{array}{l}\text { Grade } \\
\text { 3-4 TRAEs, n (\%) }\end{array}$ & $\begin{array}{l}\text { Grade } \\
5 \text { TRAEs, n (\%) }\end{array}$ & Ref. \\
\hline Advanced UC & 20 & Any & 1 March 2018 & $25(8.7-49.1)^{\dagger}$ & NE (6.5-NE) & 5.4 (1.3-NE) & $10(50)$ & $1(5)^{\ddagger}$ & [8] \\
\hline $\begin{array}{l}\text { Metastatic } \\
\text { NSCLC }\end{array}$ & 21 & Any & 1 March 2018 & $33(14.6-57.0)^{\dagger}$ & 10.9 (2.4-NE) & $5.9(2.3-13.8)$ & $12(57)$ & $1(5)^{\S}$ & [8] \\
\hline $\begin{array}{l}\text { Metastatic } \\
\text { HNSCC }\end{array}$ & 22 & Any & 1 March 2018 & $46(24.4-67.8)^{\dagger}$ & $8.2(2.2-12.6)$ & $4.7(4.0-9.8)$ & $16(73)$ & $0(0)$ & [8] \\
\hline $\begin{array}{l}\text { Unresectable } \\
\mathrm{HCC}\end{array}$ & $100 \mathbb{I}$ & First line & 31 October 2019 & $46(36.0-56.3)^{\#}$ & 8.6 (6.9-NE) & $9.3(5.6-9.7)$ & $64(64)$ & $3(3)^{\dagger \dagger}$ & [27] \\
\hline $\begin{array}{l}\text { Advanced } \\
\text { melanoma }\end{array}$ & 21 & Any & 1 March 2018 & $48(25.7-70.2)^{\dagger}$ & 12.5 (2.7-NE) & $5.5(2.6-15.8)$ & $14(67)$ & $0(0)$ & [8] \\
\hline Advanced EC & 108 & Any & 10 January 2019 & $39(29.7-48.7)^{\dagger}$ & $21.2(7.6-\mathrm{NE})$ & $7.4(5.3-8.7)$ & $83(66.9)$ & $2(2)^{\ddagger \ddagger}$ & [26] \\
\hline Metastatic RCC & 104 & Any & 9 April 2020 & $55(45.0-65.0)^{\S \S}$ & $12(9.0-18.0)$ & $11.7(9.4-17.7)$ & NR II & $2(2)^{\# \#}$ & [25] \\
\hline
\end{tabular}

$\dagger$ Proportion of patients with confirmed complete or partial response by independent review per immune-related RECIST.

$\ddagger$ Gastrointestinal hemorrhage.

§pulmonary hemorrhage.

$\mathbb{I}$ Of 104 enrolled patients, 100 were included in first-line analysis.

\#Proportion of patients with complete or partial response by independent imaging review per modified RECIST.

†† One patient died due to acute respiratory failure/acute respiratory distress; one died due to abnormal hepatic function and one due to intestinal perforation.

¥¥ One patient died due to sepsis caused by an Escherichia coli infection and one patient died due to intracranial hemorrhage.

$\S \S$ Proportion of patients with confirmed complete or partial response by investigator assessment per immune-related RECIST.

II Grade 3 TRAEs (hypertension, 19\%; diarrhea 9\%; proteinuria, 8\%; fatigue, 5\%; nausea 2\%; arthralgia 1\%); grade 4 TRAEs (increased lipase, diverticulitis, large intestine perforation and myocardial infarction).

\#\# One patient died due to upper gastrointestinal hemorrhage and one had sudden death.

DOR: Duration of response; EC: Endometrial carcinoma; HCC: Hepatocellular carcinoma; HNSCC: Head and neck squamous cell carcinoma; NE: Not estimable; NR: Not reported; NSCLC: Non-small-cell lung cancer; ORR: Objective response rate; PFS: Progression-free survival; RCC: Renal cell carcinoma; RECIST: Response Evaluation Criteria in Solid Tumors; TRAE: Treatment-related adverse event; UC: Urothelial carcinoma.

and increased aspartate aminotransferase (12.6\%) [29]. AEs with lenvatinib monotherapy generally occur early and resolve with dose modifications, supportive care and concomitant medications [30]. In the Phase III SELECT trial assessing lenvatinib in radioactive iodine-refractory differentiated thyroid cancer, the most frequent $\mathrm{AE}$ was hypertension (68\%) [31] and $47 \%$ of patients experienced the first occurrence of hypertension within the first cycle of treatment (28 days) [32]. Other common AEs were diarrhea (67\%), fatigue, asthenia, malaise (each, 67\%), proteinuria (32\%), rash (23\%) and palmar-plantar erythrodysesthesia syndrome $(33 \%)$, which had a median time to onset ranging from 3.0 to 12.1 weeks [30]; the median time to resolution of these AEs ranged from 5.9 to 20.0 weeks.

Patients with short dose interruptions ( $<10 \%$ of total treatment duration) in the Phase III SELECT trial had a greater magnitude of progression-free survival benefit compared with those with longer dose interruptions [33]. This finding highlights the importance of closely monitoring patients for AEs to lenvatinib and timely implementation of dose interruptions, reductions or both to obtain optimum lenvatinib treatment benefit.

Pembrolizumab

The most frequent AEs (of any grade) associated with pembrolizumab monotherapy across clinical studies in approximately 5000 patients with cancer include fatigue (34.1\%), rash (22.7\%), nausea (21.7\%), diarrhea (21.5\%) and pruritus (20.2\%) [34]. The combination of lenvatinib and pembrolizumab has demonstrated a manageable safety profile. In the Phase Ib/II study 111/KEYNOTE-146 trial involving patients with advanced solid tumors metastatic renal cell carcinoma, endometrial cancer, HNSCC, melanoma, NSCLC or urothelial cancer - treatmentrelated AEs (TRAEs) with the combination were reported by $97 \%$ of patients; the most common being fatigue (58\%), diarrhea (52\%), hypertension (47\%), hypothyroidism (42\%) and decreased appetite (39\%) [8]. Grade 3-5 TRAEs occurred in $67 \%$ of patients; most commonly hypertension, fatigue, diarrhea, proteinuria and increased lipase levels [8]. TRAEs led to discontinuation (12-15\% pembrolizumab; $12-15 \%$ lenvatinib) or interruption/dose reduction (45-70\% pembrolizumab; $63-85 \%$ lenvatinib) $[8,25,26]$. Six treatment-related deaths have occurred in this study: one patient with urothelial cancer with gastrointestinal hemorrhage, one patient with NSCLC with a pulmonary hemorrhage, two patients with metastatic clear cell renal cell carcinoma (one with gastrointestinal hemorrhage and one had sudden death) and two patients with endometrial cancer (one with sepsis caused by Escherichia coli infection and one with intracranial hemorrhage) (Table 2) [8,25,26]. The combination was also 

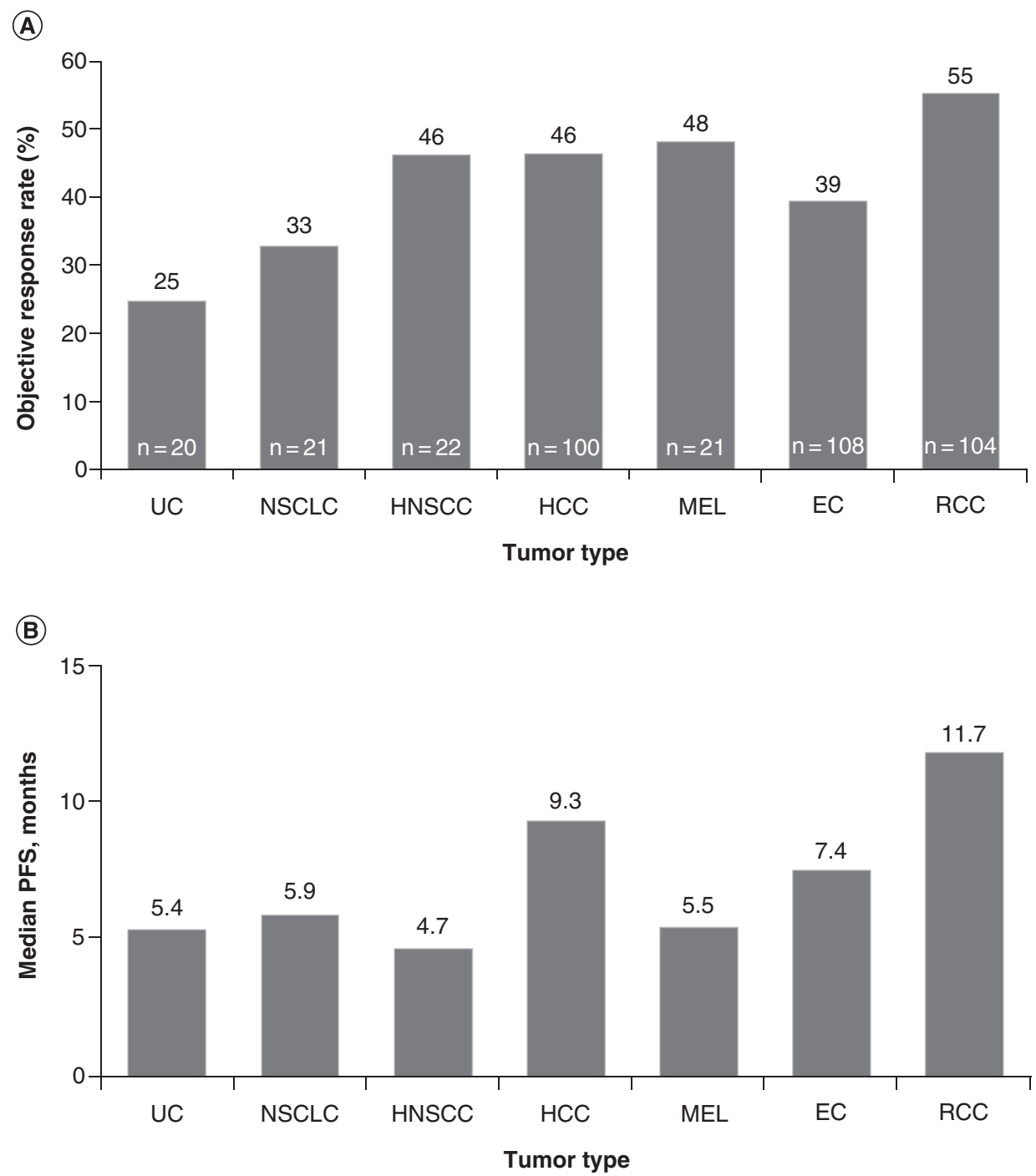

Figure 1. Summary of efficacy outcomes with lenvatinib and pembrolizumab. (A) Objective response rate ${ }^{\dagger}$ and (B) median progression-free survival ${ }^{\dagger}$ in patients with advanced solid tumors enrolled in Phase I/II trials of lenvatinib + pembrolizumab (study 111/keynote-146; study 116/KEYNOTE-524) [8,25-27].

${ }^{\dagger}$ By independent review per irRECIST for UC, NSCLC, HNSCC, MEL and EC; by investigator assessment per irRECIST for RCC; by independent imaging review per modified RECIST for HCC.

EC: Endometrial cancer; HCC: Hepatocellular carcinoma; HNSCC: Head and neck squamous cell carcinoma; irRECIST: Immune-related Response Evaluation Criteria in Solid Tumors; MEL: Melanoma; NSCLC: Non-small-cell lung cancer; PFS: Progression-free survival; RCC: Renal cell carcinoma; UC: Urothelial carcinoma.

considered tolerable in the Phase Ib study 116/KEYNOTE-524 trial in patients with previously untreated and unresectable HCC [27]. Grade 3 and 4 TRAEs occurred in 63 and 1\% of patients, respectively, with hypertension being the most commonly reported grade 3 TRAE (17\%) [27]. Three patients in this study have died due to TRAEs; one due to acute respiratory failure/acute respiratory distress syndrome, one due to intestinal perforation and one due to abnormal hepatic function [27]. No new safety signals emerged in studies evaluating the combination of lenvatinib and pembrolizumab $[8,26,27]$.

\section{LEAP clinical development program}

The promising results from study 111/KEYNOTE-146 [8,25,26] and study 116/KEYNOTE-524 [27] led to the development of the LEAP program, which is currently evaluating the safety and relative efficacy of lenvatinib plus pembrolizumab with or without chemotherapy in several tumor types. The LEAP program involves a broad spectrum of tumors in a variety of settings where new treatment options are needed (Table 3): advanced endometrial 
Table 3. LEAP program.

\begin{tabular}{|c|c|c|c|c|c|c|c|c|}
\hline $\begin{array}{l}\text { Trial number, } \\
\text { Trial ID }\end{array}$ & Tumor type & Patient population & Treatment & $\begin{array}{l}\text { Line of } \\
\text { therapy }\end{array}$ & $\begin{array}{l}\text { Primary end } \\
\text { point(s) }\end{array}$ & Phase/n & $\begin{array}{l}\text { Estimated } \\
\text { study } \\
\text { completion } \\
\text { date }\end{array}$ & Notes on design \\
\hline $\begin{array}{l}\text { LEAP-001, } \\
\text { NCT03884101 }\end{array}$ & $\begin{array}{l}\text { Endometrial } \\
\text { carcinoma }\end{array}$ & $\begin{array}{l}\text { Stage III, IV or recurrent } \\
\text { endometrial carcinoma (prior } \\
\text { radiation/chemoradiation/ } \\
\text { hormonal therapy permitted) }\end{array}$ & $\begin{array}{l}\text { Arm 1: } \\
\text { lenvatinib + } \\
\text { pembrolizumab } \\
\text { Arm 2: paclitaxel } \\
+ \text { carboplatin }\end{array}$ & $1 \mathrm{~L}$ & $\begin{array}{l}\text { PFS } \\
\text { OS }\end{array}$ & III/720 & 10 April 2023 & $\begin{array}{l}\text { - Active comparator } \\
\text { - Randomized } \\
\text { - International } \\
\text { - 31-months } \\
\text { PFS/45-months OS } \\
\text { - Imaging: Q9W; } \\
\text { >54 weeks FU Q12W }\end{array}$ \\
\hline $\begin{array}{l}\text { LEAP-002, } \\
\text { NCT03713593 }\end{array}$ & $\mathrm{HCC}$ & $\begin{array}{l}\text { Previously untreated advanced } \\
\mathrm{HCC}, \mathrm{BCLC} \text { stage } \mathrm{C} \text { disease or } \\
\text { stage B disease refractory to } \\
\text { locoregional therapy and not } \\
\text { amenable to curative approach } \\
\text { and Child-Pugh class A liver score }\end{array}$ & $\begin{array}{l}\text { Arm 1: } \\
\text { lenvatinib }+ \\
\text { pembrolizumab } \\
\text { Arm 2: } \\
\text { lenvatinib } \\
+ \text { placebo }\end{array}$ & $1 \mathrm{~L}$ & $\begin{array}{l}\text { PFS } \\
\text { OS }\end{array}$ & III/750 & 13 May 2022 & $\begin{array}{l}\text { - Active controlled } \\
\text { - Randomized } \\
\text { - International } \\
\text { - 44-months } \\
\text { PFS/44-months OS } \\
\text { - Imaging: Q9W }\end{array}$ \\
\hline $\begin{array}{l}\text { LEAP-003, } \\
\text { NCT03820986 }\end{array}$ & Melanoma & $\begin{array}{l}\text { Previously untreated advanced } \\
\text { (stage III/IV) melanoma }\end{array}$ & $\begin{array}{l}\text { Arm 1: } \\
\text { lenvatinib }+ \\
\text { pembrolizumab } \\
\text { Arm 2: } \\
\text { pembrolizumab } \\
+ \text { placebo }\end{array}$ & $1 \mathrm{~L}$ & $\begin{array}{l}\text { PFS } \\
\text { OS }\end{array}$ & III/660 & 6 April 2024 & $\begin{array}{l}\text { - Placebo controlled } \\
\text { - Randomized } \\
\text { - International } \\
\text { - 24-months } \\
\text { PFS/24-months OS } \\
\text { - Imaging: Q9W; >54 to } \\
<102 \text { weeks FU Q12W; } \\
>102 \text { weeks FU Q24W }\end{array}$ \\
\hline $\begin{array}{l}\text { LEAP-004, } \\
\text { NCT03776136 }\end{array}$ & Melanoma & $\begin{array}{l}\text { Advanced (stage III/IV) } \\
\text { melanoma that progressed } \\
\text { following anti-PD-1/PD-L1 } \\
\text { monoclonal antibody treatment } \\
\text { as monotherapy or combination } \\
\text { therapy }\end{array}$ & $\begin{array}{l}\text { Arm 1: } \\
\text { lenvatinib }+ \\
\text { pembrolizumab }\end{array}$ & $\geq 2 \mathrm{~L}$ & ORR & $\mathrm{II} / 100$ & 15 June 2021 & $\begin{array}{l}\text { - Single-arm } \\
\text { - Open-label } \\
\text { - International } \\
\text { - 36-months ORR } \\
\text { - Imaging: Q9W; >54 to } \\
<102 \text { weeks FU Q12W; } \\
>102 \text { weeks FU Q24W }\end{array}$ \\
\hline $\begin{array}{l}\text { LEAP-005, } \\
\text { NCT03797326 }\end{array}$ & $\begin{array}{l}\text { TNBC, ovarian } \\
\text { cancer, gastric } \\
\text { cancer, CRC, } \\
\text { GBM, biliary } \\
\text { tract cancer }^{\dagger}\end{array}$ & $\begin{array}{l}\text { Select advanced solid tumors that } \\
\text { progressed on or since last } \\
\text { treatment }\end{array}$ & $\begin{array}{l}\text { Arm 1: } \\
\text { lenvatinib }+ \\
\text { pembrolizumab }\end{array}$ & $\geq 2 \mathrm{~L}$ & $\begin{array}{l}\text { ORR (initial) } \\
\text { ORR } \\
\text { (expansion) } \\
\text { AEs } \\
\text { Discont due } \\
\text { to AE }\end{array}$ & $11 / 600$ & $\begin{array}{l}24 \text { February } \\
2024\end{array}$ & $\begin{array}{l}\text { - Single-arm } \\
\text { - Open-label } \\
\text { - International } \\
\text { - } 60 \text {-months ORR by } \\
\text { investigator } 60 \text {-months } \\
\text { ORR by BICR/60-months } \\
\text { AEs/60-months } \\
\text { discontinuation due to } \\
\text { AEs } \\
\text { - Imaging: Q9W; }>54 \text { to } \\
<102 \text { weeks FU Q12W; } \\
>102 \text { weeks FU Q24W }\end{array}$ \\
\hline $\begin{array}{l}\text { LEAP-006, } \\
\text { NCT03829319 }\end{array}$ & $\begin{array}{l}\text { Non-squamous } \\
\text { NSCLC }\end{array}$ & $\begin{array}{l}\text { Previously untreated metastatic } \\
\text { nonsquamous NSCLC }\end{array}$ & $\begin{array}{l}\text { Arm 1: } \\
\text { pemetrexed + } \\
\text { platinum } \\
\text { chemotherapy + } \\
\text { pembrolizumab } \\
\text { + lenvatinib } \\
\text { Arm 2: } \\
\text { pemetrexed + } \\
\text { platinum } \\
\text { chemotherapy + } \\
\text { pembrolizumab } \\
\text { + placebo }\end{array}$ & $1 \mathrm{~L}$ & $\begin{array}{l}\text { Part 1: DLTs, } \\
\text { AEs, discont. } \\
\text { due to AEs } \\
\text { Part 2: PFS, } \\
\text { OS }\end{array}$ & III/726 & 21 June 2024 & $\begin{array}{l}\text { - Placebo controlled } \\
\text { - Randomized } \\
\text { - International } \\
\text { - Part 1: 3-wk } \\
\text { DLTs/27-months AEs } \\
\text { - Part 2: } 24 \text {-months } \\
\text { PFS/60-months OS } \\
\text { - Imaging: Q6W; >18 to } \\
\text { <54 weeks FU Q9W; } \\
>54 \text { weeks FU Q12W }\end{array}$ \\
\hline $\begin{array}{l}\text { LEAP-007, } \\
\text { NCT03829332 }\end{array}$ & NSCLC & $\begin{array}{l}\text { Previously untreated, advanced } \\
\text { (Stage IV), PD-L1 positive (TPS } \\
\geq 1 \% \text { ) NSCLC }\end{array}$ & $\begin{array}{l}\text { Arm 1: } \\
\text { lenvatinib }+ \\
\text { pembrolizumab } \\
\text { Arm 2: } \\
\text { pembrolizumab } \\
+ \text { placebo }\end{array}$ & $1 \mathrm{~L}$ & $\begin{array}{l}\text { PFS } \\
\text { OS }\end{array}$ & III/620 & 8 March 2024 & $\begin{array}{l}\text { - Active controlled } \\
\text { - Randomized } \\
\text { - International } \\
\text { - 24-months } \\
\text { PFS/60-months OS } \\
\text { - Imaging: Q9W; } \\
\text { >54 weeks FU Q12W }\end{array}$ \\
\hline
\end{tabular}

$\dagger$ Patients with additional malignancy such as basal cell carcinoma of skin, squamous cell carcinoma of the skin or in situ cervical cancer or in situ breast cancer that has undergone potentially curative therapy were allowed.

¥Investigator's choice of paclitaxel, docetaxel, cetuximab or capecitabine.

1L: First line; 2L: Second line; 22L: Second line or greater; AE: Adverse event; BCLC: Barcelona Clinic Liver Cancer; BICR: Blinded independent central review; CPS: Combined positive score; CRC: Colorectal cancer; discont: Discontinued; DLT: Dose-limiting toxicity; FU: Follow-up; GBM: Glioblastoma multiforme; HCC: Hepatocellular carcinoma; HNSCC: Head and neck squamous cell carcinoma; mo: Month; NSCLC: Non-small-cell lung cancer; ORR: Objective response rate; OS: Overall survival; PD: Progressive disease; PD-1: Programmed death 1; PD-L1: Programmed death-ligand 1; PFS: Progression-free survival; Q6W: Every 6 weeks; Q9W: Every 9 weeks; Q12W: Every 12 weeks; Q24 weeks: Every 24 weeks; RECIST 1.1: Response Evaluation Criteria in Solid Tumors, version 1.1; TACE: Transarterial chemoembolization; TNBC: Triple-negative breast cancer; yr: Year; TPS: Tumor proportion score; Wk: Week. 
Table 3. LEAP program (cont.).

\begin{tabular}{|c|c|c|c|c|c|c|c|c|}
\hline $\begin{array}{l}\text { Trial number, } \\
\text { Trial ID }\end{array}$ & Tumor type & Patient population & Treatment & $\begin{array}{l}\text { Line of } \\
\text { therapy }\end{array}$ & $\begin{array}{l}\text { Primary end } \\
\text { point(s) }\end{array}$ & Phase/n & $\begin{array}{l}\text { Estimated } \\
\text { study } \\
\text { completion } \\
\text { date }\end{array}$ & Notes on design \\
\hline $\begin{array}{l}\text { LEAP-008, } \\
\text { NCT03976375 }\end{array}$ & NSCLC & $\begin{array}{l}\text { Metastatic NSCLC that } \\
\text { progressed during/after } \\
\text { platinum doublet chemotherapy } \\
\text { or on treatment with } \\
\text { anti-PD-1/PD-L1 monoclonal } \\
\text { antibody as monotherapy or } \\
\text { combination therapy }\end{array}$ & $\begin{array}{l}\text { Arm 1: } \\
\text { lenvatinib }+ \\
\text { pembrolizumab } \\
\text { Arm 2: } \\
\text { docetaxel } \\
\text { Arm 3: } \\
\text { lenvatinib }\end{array}$ & $\geq 2 \mathrm{~L}$ & $\begin{array}{l}\text { PFS } \\
\text { OS }\end{array}$ & III/405 & $\begin{array}{l}23 \text { Febru- } \\
\text { ary } 2026\end{array}$ & $\begin{array}{l}\text { - Active comparators } \\
\text { - Randomized } \\
\text { - Open-label } \\
\text { - International } \\
\text { - 48-months } \\
\text { OS/36-months PFS } \\
\text { - Imaging: Q6W; }>36 \text { to } \\
<54 \text { weeks FU Q9W; } \\
>54 \text { weeks FU Q12W }\end{array}$ \\
\hline $\begin{array}{l}\text { LEAP-009, } \\
\text { NCT04428151 }\end{array}$ & HNSCC & $\begin{array}{l}\text { Recurrent/metastatic HNSCC of } \\
\text { the oral cavity, oropharynx, } \\
\text { hypopharynx and/or larynx that } \\
\text { progressed during/after } \\
\text { platinum chemotherapy } \\
\text { with/without cetuximab and } \\
\text { progressed during/after } \\
\text { anti-PD-1/PD-L1 monotherapy or } \\
\text { combination therapy }\end{array}$ & $\begin{array}{l}\text { Arm 1: } \\
\text { lenvatinib }+ \\
\text { pembrolizumab } \\
\text { Arm 2: SOC } \\
\text { chemotherapy } \ddagger \\
\text { Arm 3: } \\
\text { lenvatinib }\end{array}$ & $\geq 2 \mathrm{~L}$ & ORR & $11 / 400$ & $\begin{array}{l}18 \mathrm{Au}- \\
\text { gust } 2024\end{array}$ & $\begin{array}{l}\text { - Active comparators } \\
\text { - Open-label } \\
\text { - Randomized } \\
\text { - International } \\
\text {-48-months ORR } \\
\text { - Imaging: Q6W; } \\
\text { >52 weeks FU Q9W }\end{array}$ \\
\hline $\begin{array}{l}\text { LEAP-010, } \\
\text { NCT04199104 }\end{array}$ & HNSCC & $\begin{array}{l}\text { Recurrent/metastatic HSNCC of } \\
\text { the oral cavity, oropharynx, } \\
\text { hypopharynx, or larynx with } \\
\text { PD-L1 CPS } \geq 1\end{array}$ & $\begin{array}{l}\text { Arm 1: } \\
\text { lenvatinib }+ \\
\text { pembrolizumab } \\
\text { Arm 2: } \\
\text { pembrolizumab } \\
+ \text { placebo }\end{array}$ & $1 \mathrm{~L}$ & $\begin{array}{l}\text { ORR } \\
\text { PFS } \\
\text { OS }\end{array}$ & $\mathrm{III} / 500$ & 13 April 2024 & $\begin{array}{l}\text { - Placebo controlled } \\
\text { - Randomized } \\
\text { - International } \\
\text { - 24-months } \\
\text { ORR/30-months } \\
\text { PFS/44-months OS } \\
\text { - Imaging: Q6W; } \\
>48 \text { weeks FU Q9W }\end{array}$ \\
\hline $\begin{array}{l}\text { LEAP-011, } \\
\text { NCT03898180 }\end{array}$ & $\begin{array}{l}\text { Urothelial } \\
\text { carcinoma }\end{array}$ & $\begin{array}{l}\text { Previously untreated, } \\
\text { advanced/unresectable or } \\
\text { metastatic urothelial carcinoma } \\
\text { that is ineligible for } \\
\text { platinum-containing } \\
\text { chemotherapy or } \\
\text { cisplatin-ineligible with PD-L1 } \\
\text { CPS } \geq 10\end{array}$ & $\begin{array}{l}\text { Arm 1: } \\
\text { lenvatinib }+ \\
\text { pembrolizumab } \\
\text { Arm 2: } \\
\text { pembrolizumab } \\
+ \text { placebo }\end{array}$ & $1 \mathrm{~L}$ & $\begin{array}{l}\text { PFS } \\
\text { OS }\end{array}$ & III/694 & $\begin{array}{l}30 \text { Decem- } \\
\text { ber } 2022\end{array}$ & $\begin{array}{l}\text { - Active controlled } \\
\text { - Randomized } \\
\text { - International } \\
\text { - 40-months } \\
\text { PFS/40-months OS } \\
\text { - Imaging: Q6W; >24 to } \\
<60 \text { weeks FU Q9W; } \\
>60 \text { weeks FU Q12W }\end{array}$ \\
\hline $\begin{array}{l}\text { LEAP-012, } \\
\text { NCT04246177 }\end{array}$ & $\mathrm{HCC}$ & $\begin{array}{l}\text { Incurable, nonmetastatic, } \\
\text { previously untreated HCC } \\
\text { localized to the liver with } \\
\text { Child-Pugh class A liver score }\end{array}$ & $\begin{array}{l}\text { Arm 1: } \\
\text { lenvatinib + } \\
\text { pembrolizumab } \\
+ \text { TACE } \\
\text { Arm 2: placebo } \\
+ \text { TACE }\end{array}$ & $1 \mathrm{~L}$ & $\begin{array}{l}\text { PFS } \\
\text { OS }\end{array}$ & III/950 & $\begin{array}{l}31 \text { December } \\
2029\end{array}$ & $\begin{array}{l}\text { - Active controlled } \\
\text { - Randomized } \\
\text { - International } \\
\text { - 60-months } \\
\text { PFS/60-months OS } \\
\text { - Imaging: Q9W }\end{array}$ \\
\hline \multicolumn{9}{|c|}{$\begin{array}{l}\dagger \text { †atients with additional malignancy such as basal cell carcinoma of skin, squamous cell carcinoma of the skin or in situ cervical cancer or in situ breast cancer that has undergone potentially } \\
\text { curative therapy were allowed. } \\
\text { ¥Investigator's choice of paclitaxel, docetaxel, cetuximab or capecitabine. } \\
\text { 1L: First line; 2L: Second line; } \geq 2 \text { L: Second line or greater; AE: Adverse event; BCLC: Barcelona Clinic Liver Cancer; BICR: Blinded independent central review; CPS: Combined positive score; } \\
\text { CRC: Colorectal cancer; discont: Discontinued; DLT: Dose-limiting toxicity; FU: Follow-up; GBM: Glioblastoma multiforme; HCC: Hepatocellular carcinoma; HNSCC: Head and neck squamous } \\
\text { cell carcinoma; mo: Month; NSCLC: Non-small-cell lung cancer; ORR: Objective response rate; OS: Overall survival; PD: Progressive disease; PD-1: Programmed death 1; PD-L1: Programmed } \\
\text { death-ligand 1; PFS: Progression-free survival; Q6W: Every } 6 \text { weeks; Q9W: Every } 9 \text { weeks; Q12W: Every } 12 \text { weeks; Q24 weeks: Every } 24 \text { weeks; RECIST 1.1: Response Evaluation Criteria in } \\
\text { Solid Tumors, version 1.1; TACE: Transarterial chemoembolization; TNBC: Triple-negative breast cancer; yr: Year; TPS: Tumor proportion score; Wk: Week. }\end{array}$} \\
\hline
\end{tabular}

cancer (first line); advanced HCC (first line); advanced melanoma (first line and $\geq$ second line); relapsed or refractory triple-negative breast cancer, advanced ovarian cancer, advanced gastric cancer, recurrent colorectal cancer, glioblastoma multiforme, biliary tract cancer (all $\geq$ second line); NSCLC (first and $\geq$ second line); HNSCC (first line and $\geq$ second line), urothelial cancer (first line); and HCC (Barcelona Liver Clinic Cancer stage C or stage $\mathrm{B}$ refractory to locoregional therapy) (first line). The LEAP program includes nine Phase III studies (LEAP-001, LEAP-002, LEAP-003, LEAP-006, LEAP-007, LEAP-008, LEAP-010, LEAP-011 and LEAP-012), each with planned enrollment between 405 and 950 patients; as well as three Phase II studies (LEAP-004, LEAP-005 and LEAP-009) (Table 3).

\section{Conclusion}

Based on the promising results from study 111/KEYNOTE-146 and Study 116/KEYNOTE-524, the combination of lenvatinib plus pembrolizumab or triple therapy with lenvatinib plus pembrolizumab plus chemotherapy is 
anticipated to provide superior antitumor activity in the selected tumor types compared with either agent alone or standard of care. Interim results from study 111 KEYNOTE-146 has resulted in the combination of pembrolizumab plus lenvatinib being approved in the USA, Australia and Canada for the treatment of advanced endometrial carcinoma that is not MSI-H or dMMR, for patients who have disease progression following prior systemic therapy and are not candidates for curative surgery or radiotherapy. In tumor types where lenvatinib or pembrolizumab is already approved as monotherapy, the combination may result in improved efficacy.

The safety profiles of lenvatinib and pembrolizumab are well established as monotherapies. The safety of the combination is consistent with the safety of each individual agent and there have been no new safety signals. Therefore, the combination of lenvatinib and pembrolizumab is expected to be tolerable in the LEAP program. As such, we anticipate that combination therapy with lenvatinib plus pembrolizumab will be an important potential new treatment regimen for several solid cancers where therapeutic options are currently limited.

\section{Executive summary}

- The development of immunotherapies and targeted agents has significantly improved outcomes in a number of cancers; however, innate and acquired resistance to these therapies remains a challenge.

- One strategy being investigated to overcome resistance is to use combination therapy, allowing multiple signaling pathways to be targeted simultaneously.

- The LEAP clinical trial program is designed to investigate the efficacy and safety of lenvatinib in combination with pembrolizumab in a range of solid tumors.

Lenvatinib

- Lenvatinib is a multitargeted kinase inhibitor that has activity against a number of angiogenic kinases, including VEGF and FGF receptors. Lenvatinib also has antiproliferative and immunomodulatory properties.

- Lenvatinib is approved by the US FDA for the treatment of radioactive iodine-refractory differentiated thyroid cancer, for first-line treatment of unresectable hepatocellular carcinoma, in combination with everolimus for second-line treatment of advanced renal cell carcinoma and in combination with pembrolizumab for second-line treatment of endometrial carcinoma that is not microsatellite instability high or mismatch repair deficient.

Pembrolizumab

- Pembrolizumab is an anti-PD-1 antibody that counteracts downregulation of the antitumor immune response mediated by the PD-1 pathway.

- Pembrolizumab is approved by the FDA for the treatment of a range of solid and hematologic malignancies.

Rationale for lenvatinib \& pembrolizumab combination therapy

- In preclinical investigation, lenvatinib plus pembrolizumab produced greater reductions in tumor volume and higher response rates than either agent alone and had immunomodulatory properties that may enhance antitumor immune response.

- Preliminary results from ongoing Phase Ib/II studies investigating lenvatinib plus pembrolizumab have reported manageable toxicity, robust antitumor activity and durable responses across seven tumor types, with no new safety signals.

\section{LEAP clinical trial program}

- The promising results from the Phase $\mathrm{Ib} / \mathrm{Il}$ studies investigating lenvatinib plus pembrolizumab led to development of the LEAP clinical trial program.

- The LEAP program includes nine Phase III studies and three Phase II studies investigating lenvatinib plus pembrolizumab with or without chemotherapy in a range of solid tumor types including: endometrial cancer, hepatocellular carcinoma, melanoma, triple-negative breast cancer, ovarian cancer, gastric cancer, colorectal cancer, glioblastoma multiforme, biliary tract cancer, non-small cell lung cancer, head and neck squamous cell carcinoma and urothelial cancer.

Conclusion

- Based on promising preliminary results from several ongoing trials, it is expected that lenvatinib plus pembrolizumab or triple therapy with lenvatinib plus pembrolizumab and chemotherapy may potentially be important new regimens for several solid cancers that currently have limited therapeutic options.

\section{Author contributions}

Conception, design or planning of the study was performed by C Ductus, Y Funahashi, E Schmidt and M. Taylor. Acquisition of the data was performed by C Ductus, D Rasco, E Schmidt and M Taylor. Analysis of the data was performed by C Ductus, E Schmidt and M Taylor. Interpretation of the results was performed by C Ductus, G Lubiniecki, E Pinheiro, D Rasco, E Schmidt and M Taylor. Drafting of the manuscript was performed by Y Funahashi, E Schmidt and M Taylor. Critically reviewing or revising the manuscript 
for important intellectual content was performed by C Ductus, G Lubiniecki, E Pinheiro, D Rasco, E Schmidt and M Taylor. All the authors reviewed the final version and agreed with the content and the decision to submit.

Financial \& competing interests disclosure

Funding for the LEAP trials was provided by Merck Sharp \& Dohme Corp., a subsidiary of Merck \& Co., Inc., NJ, USA and Eisai Inc., Woodcliff Lake, NJ, USA. M Taylor reports funding to institution for conduct of clinical research from Bristol Myers Squibb, Eisai Inc, Merck Sharp \& Dohme Corp., a subsidiary of Merck \& Co., Inc., NJ, USA, Pharmacyclics, AstraZeneca, Incyte, EMD Serono, Novartis, Seattle Genetics, Exelixis, AbbVie, Genentech, Eli Lilly, Roche, Acerta Pharma, Genzyme and Pfizer. M Taylor also reports honoraria and consulting/advisory board membership for Bristol Myers Squibb, Eisai Inc., Novartis, Bayer, Sanofi Genzyme, Array Biopharma, Loxo Oncology, Blueprint Medicines and Arqule. E Schmidt is an employee of Merck Sharp \& Dohme Corp., a subsidiary of Merck \& Co., Inc., NJ, USA and shareholder for Merck \& Co., Inc., NJ, USA. C Ductus is an employee of Eisai Inc. E. Pinheiro is an employee of Merck Sharp \& Dohme Corp., a subsidiary of Merck \& Co., Inc., NJ, USA. Y Funahashi reports personal fees as an employee of Eisai Co., Ltd. In addition, Y Funahashi has a patent, W00232872, issued. G Lubiniecki is an employee of Merck Sharp \& Dohme Corp., a subsidiary of Merck \& Co., Inc., NJ, USA and stock owner of Merck \& Co., Inc., NJ, USA. D Rasco reports research funding from Merck Sharp \& Dohme Corp., a subsidiary of Merck \& Co., Inc., NJ, USA, Eisai Inc., Exelixis, Arcus, Incyte, Macrogenics, Jounce, Regeneron and Tesaro. The authors have no other relevant affiliations or financial involvement with any organization or entity with a financial interest in or financial conflict with the subject matter or materials discussed in the manuscript apart from those disclosed.

Medical writing and/or editorial assistance was provided by J Walker, PhD, and D Mitra, PhD, of ApotheCom (Yardley, PA, USA). This assistance was funded by Merck Sharp \& Dohme and Eisai Inc., Woodcliff Lake, NJ, USA.

Open access

This work is licensed under the Attribution-NonCommercial-NoDerivatives 4.0 Unported License. To view a copy of this license, visit http://creativecommons.org/licenses/by-nc-nd/4.0/

\section{References}

Papers of special note have been highlighted as: $\bullet$ of interest; $\bullet \bullet$ of considerable interest

1. Ribas A, Wolchok JD. Cancer immunotherapy using checkpoint blockade. Science 359(6382), 1350-1355 (2018).

2. Bhullar KS, Lagaron NO, McGowan EM et al. Kinase-targeted cancer therapies: progress, challenges and future directions. Mol. Cancer 17(1), 48 (2018).

3. Seebacher NA, Stacy AE, Porter GM, Merlot AM. Clinical development of targeted and immune based anti-cancer therapies. J. Exp. Clin. Cancer Res. 38(1), 156 (2019).

4. Shergold AL, Millar R, Nibbs RJB. Understanding and overcoming the resistance of cancer to PD-1/PD-L1 blockade. Pharmacol. Res. 145, 104258 (2019).

5. Gide TN, Wilmott JS, Scolyer RA, Long GV. Primary and acquired resistance to immune checkpoint inhibitors in metastatic melanoma. Clin. Cancer Res. 24(6), 1260-1270 (2018).

6. KEYTRUDA $^{\circledR}$ (pembrolizumab) injection, for intravenous use. 11/2020 Merck Sharp \& Dohme Corp., NJ, USA (2020).

7. LENVIMA $^{\circledR}$ (lenvatinib) [prescribing information]. Eisai Inc., NJ, USA (2020).

8. Taylor MH, Lee $\mathrm{CH}$, Makker V et al. Phase IB/II trial of lenvatinib plus pembrolizumab in patients with advanced renal cell carcinoma, endometrial cancer and other selected advanced solid tumors. J. Clin. Oncol. 38(11), 1154-1163 (2020).

- Dose-finding and initial Phase II expansion of a Phase Ib/II study which showed that lenvatinib plus pembrolizumab had manageable safety and promising antitumor activity in patients with select solid tumors.

9. Suyama K, Iwase H. Lenvatinib: a promising molecular targeted agent for multiple cancers. Cancer Control 25(1), https://doi.org/10.1177/1073274818789361 (2018) (Epub ahead of print).

10. Yamaoka T, Kusumoto $S$ ando K, Ohba M, Ohmori T. Receptor tyrosine kinase-targeted cancer therapy. Int. J. Mol. Sci. 19(11), (2018).

11. Yamamoto Y, Matsui J, Matsushima T et al. Lenvatinib, an angiogenesis inhibitor targeting VEGFR/FGFR, shows broad antitumor activity in human tumor xenograft models associated with microvessel density and pericyte coverage. Vasc. Cell 6, 18 (2014).

12. Kato $\mathrm{Y}$, Tabata K, Kimura $\mathrm{T}$ et al. Lenvatinib plus anti-PD-1 antibody combination treatment activates CD8+ T cells through reduction of tumor-associated macrophage and activation of the interferon pathway. PLoS ONE 14(2), e0212513 (2019).

13. Solinas G, Germano G, Mantovani A, Allavena P. Tumor-associated macrophages (TAM) as major players of the cancer-related inflammation. J. Leukoc. Biol. 86(5), 1065-1073 (2009).

14. Noy R, Pollard JW. Tumor-associated macrophages: from mechanisms to therapy. Immunity 41(1), 49-61 (2014). 
15. Voron T, Colussi O, Marcheteau E et al. VEGF-A modulates expression of inhibitory checkpoints on CD8+ T cells in tumors. J. Exp. Med. 212(2), 139-148 (2015).

16. Yang J, Yan J, Liu B. Targeting VEGF/VEGFR to modulate antitumor immunity. Front. Immunol. 9, 978 (2018).

17. Takase N, Koma Y, Urakawa N et al. NCAM- and FGF-2-mediated FGFR1 signaling in the tumor microenvironment of esophageal cancer regulates the survival and migration of tumor-associated macrophages and cancer cells. Cancer Lett. 380(1), 47-58 (2016).

18. LENVIMA ${ }^{\circledR}$ (lenvatinib) $4 \mathrm{mg}$ and $10 \mathrm{mg}$ hard capsules (summary of product characteristics). Frankfurt, Germany, Eisai GmbH (2020).

19. Kyi C, Postow MA. Immune checkpoint inhibitor combinations in solid tumors: opportunities and challenges. Immunotherapy 8(7), 821-837 (2016).

20. Pardoll DM. The blockade of immune checkpoints in cancer immunotherapy. Nat. Rev. Cancer 12(4), 252-264 (2012).

21. Dong Y, Sun Q, Zhang X. PD-1 and its ligands are important immune checkpoints in cancer. Oncotarget 8(2), 2171-2186 (2017).

22. Du Rusquec P, De Calbiac O, Robert M, Campone M, Frenel JS. Clinical utility of pembrolizumab in the management of advanced solid tumors: an evidence-based review on the emerging new data. Cancer Manag. Res. 11, 4297-4312 (2019).

23. Morrissey KM, Yuraszeck TM, Li CC, Zhang Y, Kasichayanula S. Immunotherapy and novel combinations in oncology: current landscape, challenges and opportunities. Clin. Transl. Sci. 9(2), 89-104 (2016).

24. Kimura T, Kato Y, Ozawa Y et al. Immunomodulatory activity of lenvatinib contributes to antitumor activity in the Hepa1-6 hepatocellular carcinoma model. Cancer Sci. 109(12), 3993-4002 (2018).

- Preclinical investigation of the antitumor and immunomodulatory activity of lenvatinib and an anti-PD-1 antibody in a Hepa1-6 syngeneic mouse model of HCC. Results showed that lenvatinib had immunomodulatory activity which enhanced its antitumor activity and that lenvatinib plus an anti-PD-1 antibody had superior antitumor activity compared with either agent alone.

25. Lee $\mathrm{CH}$, Shah AY, Hsieh JJ et al. Phase II trial of lenvatinib (LEN) plus pembrolizumab (PEMBRO) for disease progression after PD-1/PD-L1 immune checkpoint inhibitor (ICI) in metastatic clear cell renal cell carcinoma (mccRCC). J. Clin. Oncol. 38(Suppl. 15), Abstract 5008 (2020).

-. Results of the interim analysis of the renal cell carcinoma cohort of the open-label, Phase Ib/II study showed that lenvatinib plus pembrolizumab had promising antitumor activity in patients with metastatic clear cell renal cell carcinoma whose disease progressed following immune checkpoint inhibitor therapy.

26. Makker V, Taylor MH, Aghajanian C et al. Lenvatinib plus pembrolizumab in patients with advanced endometrial cancer. J. Clin. Oncol. 38(26), 2981-2992 (2020).

- Final primary efficacy analysis from the endometrial cancer cohort of a Phase Ib/II study showed that the combination of lenvatinib and pembrolizumab had promising antitumor activity regardless of microsatellite instability or mismatch-repair deficient status and was generally well tolerated.

27. Zhu AX, Finn RS, Ikeda M et al. A Phase Ib study of lenvatinib (LEN) plus pembrolizumab (PEMBRO) in unresectable hepatocellular carcinoma (uHCC). J. Clin. Oncol. 38(Suppl. 15), Abstract 4519 (2020).

-. Phase Ib study which showed that lenvatinib plus pembrolizumab had promising antitumor activity with a tolerable safety profile in patients with unresectable hepatocellular carcinoma.

28. US FDA. Simultaneous review decisions for pembrolizumab plus lenvatinib in Australia, Canada and US (2019). https://www.fda.gov/ drugs/resources-information-approved-drugs/simultaneous-review-decisions-pembrolizumab-plus-lenvatinib-australia-canada-and-us

29. Zhu C, Ma X, Hu Y et al. Safety and efficacy profile of lenvatinib in cancer therapy: a systematic review and meta-analysis. Oncotarget 7(28), 44545-44557 (2016).

- Systematic review and meta-analysis of 14 studies involving a total of 978 patients treated with lenvatinib. The analysis identified encouraging antitumor activity of lenvatinib in solid tumors and clinically meaningful survival outcomes in patients with thyroid cancer, while noting that early monitoring and effective management of adverse effects are required.

30. Haddad RI, Schlumberger M, Wirth LJ et al. Incidence and timing of common adverse events in Lenvatinib-treated patients from the SELECT trial and their association with survival outcomes. Endocrine 56(1), 121-128 (2017).

31. Schlumberger M, Tahara M, Wirth LJ et al. Lenvatinib versus placebo in radioiodine-refractory thyroid cancer. N. Engl. J. Med. 372(7), 621-630 (2015).

32. Wirth LJ, Tahara M, Robinson B et al. Treatment-emergent hypertension and efficacy in the Phase III Study of (E7080) lenvatinib in differentiated cancer of the thyroid (SELECT). Cancer 124(11), 2365-2372 (2018).

33. Tahara M, Brose MS, Wirth LJ et al. Impact of dose interruption on the efficacy of lenvatinib in a Phase III study in patients with radioiodine-refractory differentiated thyroid cancer. Eur. J. Cancer 106, 61-68 (2019).

34. European Commission approves Merck's KEYTRUDA ${ }^{\circledR}$ (pembrolizumab) as adjuvant therapy for adults with resected stage III melanoma (2018). https://www.biospace.com/article/releases/european-commission-approves-merck-s-keytruda-pembrolizumab-as-adj uvant-therapy-for-adults-with-resected-stage-iii-melanoma 